\title{
The Bail-Out! \\ Positive Political Economics of Greek-type Crises in the EMU
}

\author{
Christian Fahrholz \\ Cezary Wójcik
}

\author{
CESIFO WORKING PAPER NO. 3178 \\ CATEGORY 7: MONETARY POLICY AND INTERNATIONAL FINANCE \\ SEPTEMBER 2010
}

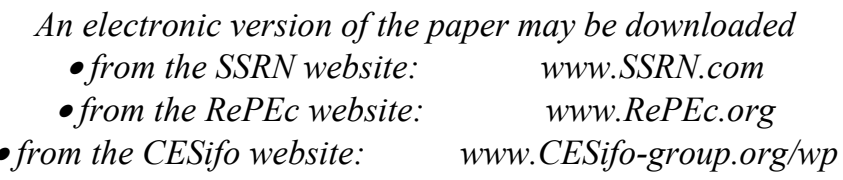




\title{
The Bail-Out! Positive Political Economics of Greek-type Crises in the EMU
}

\begin{abstract}
The Greek bail-out was highly controversial. An oft-heard assessment is that i) the bail-out was a mistake, ii) the political haggling over it was irrational and iii) the bail-out will create a moral hazard problem. Contrary to this view, our analysis suggests that, given EMU's present political-economic set-up, i) the bail-out was unavoidable, ii) the lengthy process of political haggling leading to it was understandable, and iii) the bail-out does not have to be necessarily associated with a future moral hazard problem. Based on our analysis, we suggest that the EMU's institutional design could be improved by establishing 'exit rules' and that bail-outs should be made rule-based. We have based our analysis on a political-economic, gametheoretic model that helps to understand why and how the parties involved in the Greek crisis arrived at the bail-out and on what conditions the final solution depended. The model allows tracing analytically the dynamics of the negotiation processes as well as the conditions and parameters on which the scope and limits of fiscal redistribution in EMU depends. In doing so, we formally take account of the 'negative externality' problem that has been central to policy debates related to the EMU's institutional design and has played an important role in the Greek crisis. However, contrary to the existing literature, we do not only focus on the economic aspects of such negative externality, but also look at where they emanate from and interact with political factors, in particular the dynamics of the political negotiation process within the EMU.
\end{abstract}

JEL-Code: E62, F33, H77, C70.

Keywords: Greek crisis, bail-out, negative externality, political economics, game theory, euro, EMU.

\author{
Christian Fahrholz \\ School of Economics and Business Admin. \\ Friedrich-Schiller-University Jena \\ Carl-Zeiss-Strasse 3 \\ Germany-07743 Jena \\ christian.fahrholz@uni-jena.de
}

\author{
Cezary Wójcik \\ Warsaw School of Economics \\ Al. Niepodleglości 164 \\ Poland-02-554 Warsaw \\ cezary.wojcik@sgh.waw.pl
}

We wish to thank Peter Backé, Michael Burda, Barry Eichengreen, Jeffrey Frankel, Stanisław Gomułka, Andreas Kern, Andrzej Raczko and Krzysztof Rybinski for their helpful comments and suggestions. We are also grateful to Cordelia Friesendorf and Katarzyna Laszkiewicz for their research assistance and linguistic support. Standard disclaimer applies.

Generous support by The Ernst Abbe Foundation is gratefully acknowledged.

A DAAD research grant is gratefully acknowledged. 


\section{Introduction}

With the outbreak of the Greek sovereign crisis in early 2010, the EMU confronted the biggest challenge in its decade-long history. After months of political haggling, the euro area came up with an unprecedented bail-out for Greece worth EUR 110 billion. ${ }^{1}$ The support package has proved highly controversial among economists who disagree strongly whether this has been the right policy course. Some commentators (e.g., Frankel (2010), Issing (2010) or Wyplosz (2010)) have strongly argued that providing financial support is a policy mistake, as it undermines the foundations of the EMU (i.e. particularly the 'no bail-out' clause and the prohibition of monetary financing) and thus jeopardizes the euro in the long-run by creating a moral hazard problem and hampering the Eurosystem's credibility. In contrast, others (i.e. Eichengreen (2010) or Padoa-Schioppa (2010)) have argued that letting Greece default would spread the crises to other members, like Spain or Portugal, creating a risk of the EMU breakup which would trigger "the mother of all financial crises". Hence, in their view, Europe needs to create a strong emergency financing mechanism, eventually backed by higher degree of political integration (e.g. De Grauwe (2010), see also Baldwin et al. (2010) for an interesting overview of the debate).

While the discussion has been intense, and the controversies abound, it has been so far limited only to normative policy-oriented issues, focused mostly on the economic aspects, with much less account of the political-economic considerations ${ }^{2}$ and has so far not generated formal models able to analyze the crisis. In this paper we propose a positive analysis that can serve as a framework for describing and analyzing Greek-type sovereign debt crises in the context of the EMU in a structured manner. We build on a political economic, game-theoretic model with incomplete political integration that, by taking into account the interactions between the economic and political factors, helps to understand why and how the parties involved in the Greek crisis arrived at the bail-out and on what conditions the final solution depended. We demonstrate that, conditional on the present political-economic set-up of EMU, the bail-out

\footnotetext{
${ }^{1}$ The bail-out for Greece took the form of a 3-year package of emergency loans, with EUR 80 billion offered by the euro area members and EUR 30 by the IMF. A few days later the EU established a special purpose vehicle, namely the so-called European Stabilization Mechanism (ESM), worth EUR 750 billion. The ESM involves a 3year stabilization plan that includes EUR 60 billion provided by the European Commission, EUR 440 billion provided in bilateral loans and guarantees by euro area members, as well as EUR 250 billion from the IMF. In addition, the ECB committed to the direct purchase of government bonds on the open market.

${ }^{2}$ See, for example, Fisher et al. (2007) for a survey of political-economic arguments related to the EMU issues, although without accounting for a positive modeling framework.
} 
was inevitable, i.e. a threat of default by one member that creates a negativity externality for the whole monetary union must (under identifiable conditions) result in sharing the costs of fiscal adjustment by the rest of the members. Importantly, we show that such bail-out does not need to be associated with a moral hazard problem.

One of the key novelties in our work is that we formally take account of the negative externality problem that has been central to policy debates related to EMU's institutional design since the very birth of the euro (see, for example, Gros et al. (2005) and de Haan et al. (2004) for early contributions within this debate) and played an important role in the specific case of the Greek crisis in the form of - as some commentators call it - a "bail-out blackmail" (see Mayer (2010)). However, contrary to the existing literature, we do not only focus on the economic aspects of such a negative externality, but also look at where it emanates from and how it interacts with political factors, in particular the dynamics of the political negotiation process within the EMU, i.e. to what extent a 'troubled' EMU member may negotiate a bailout due to the existence of a negative externality arising from its potential default.

Furthermore, the model also allows tracing analytically the dynamics of the negotiations process as well as the parameters on which the scope and limits of a fiscal redistribution depend. In doing so, the analysis helps to shed some light on several key policy aspects, such as: i) the conditions under which a bail-out does not generate a moral hazard problem in the long-run, ii) the role of political factors such as voters attitude towards fiscal retrenchment and their support for the European integration process, iii) how the risk of contagion to other weak members, the perceived risk of EMU break-up or the possibility of coalition-building between groups of euro area members can affect the negotiation outcome, iv) the duration of the political haggling over the bail-out.

We show that the political negotiations over the bail-out can be described by a brinkmanship threat game in which the respective brinkmanship is formalized and completed by a Nash bargaining solution. The analysis determines the scope and limits of the brinkmanship and subsequently inquires into the bargaining solution. However, contrary to the existing literature, the bargaining problem is characterized by disutility rather than utility allocations. A hallmark of the model is that haggling over fiscal adjustment costs is captured in a bargaining that renders the entire threat game analytically as well as empirically tractable (see also Fahrholz (2007)). 
The paper is composed of four sections. The next section presents our analysis in the context of the existing literature. The following section presents the modeling framework, i.e. its general structure, the nature of brinkmanship, and the subsequent bargaining. The final section concludes and discusses some policy implications.

\section{Related literature}

The Greek bail-out involved intense negotiations among euro area members and depended a great deal on political factors. At the onset of EMU, already Bordo and Jonung (1999) highlighted that that political factors will be the central determinants of the future of EMU. In such a setting, game theoretic analysis seems highly suitable and instructive.

In fact, there is already a long tradition to use the type of modeling to different aspects of international relations (see, for example, Dixit and Nalebuff (2008), Zagare and Kilgour (2000) for extensive surveys). Within this general line of research there exists also a diverse literature on applications of threat games and brinkmanship strategies respectively (see Schwarz and Sonin (2008) for a survey of related strands in literature as well as Acemoglu (2003) on general issues, at which research in economics and political science overlap). However, most of this literature has been applied mainly to political science. The few exceptions that capture economic applications address international trade negotiations (e.g., Milner and Rosendorff (1997)), exchange-rate policies (Fahrholz (2007)) or selected cases of economic history (e.g., Yared (2010); Dye and Sicotte (2006)).

Our analysis differs from the above literature as it concerns the political-economic aspects of EMU. The political-economics setting of our analysis resembles that of Alesina and Drazen (1991) who argue that domestic fiscal reforms may have significant distributional implications, so that societal groups may seek to pass the burden of fiscal adjustment costs onto other groups at the national level. However, our focus is on the mutual dependence of fiscal policy-making within EMU-member states. We particularly account for the interaction between both the national and the European sphere. In this regard, we consider the canonical 'Schelling conjecture' (Schelling (1960); Dixit (2006) for a reappraisal). This 'two-level metaphor' postulates that national executives intermediating between the national and the 
European level have to craft ratification within the domestic arena. The latter process can also be traced to a permissive consensus of voters and lobbies that can enforce substantial political conflict potential. Such a domestically constrained executive can make use of its internal 'weakness' in terms of enhancing its bargaining position, for instance, in negotiations concerning European fiscal affairs. In case there exists an opportunity of playing off national constituency against other entities and inflicting the latter actors with negative externalities such proactive stance toward moral-hazard behavior represents a 'brinkmanship' strategy. The scope and limits of such a 'threat' may thus represent bargaining leverage, for example, in European fiscal affairs depend on numerous aspects.

There exists theoretically oriented literature of both disciplines economics and political science which enquires into conditions determining corresponding strategy sets. In this respect, according models account not only for actors' preferences but also for their attitudes toward risk and time (discount rates) etc. The latter research approach is usually known as the 'Nash-program' (Binmore et al. (1986)) and traces in the seminal contributions of Nash (1950, 1953). As regards formal modeling, the number of actors involved (Mao (1993)), the way of modeling constraints - i.e. the Schelling-conjecture - including the distribution of information concerning this matter (Tarar (2001); further, Iida (1993)), and assumptions concerning discount rates shape particular threat games.

\section{Modeling framework}

In this section we outline the modeling framework. Our analysis is based on a brinkmanship game, which may be solved by a Nash bargaining solution (Nash $(1950,1953)$ ). The analysis determines the scope and limits of the brinkmanship and subsequently inquires into the bargaining solution. It demonstrates to what extent a 'troubled' EMU member may negotiate a bail-out due to the existence of a negative externality arising from its potential default.

\section{The general set-up}

In order to keep the game simple and tractable, the focus is limited to several key aspects of the political-economics design of EMU. 
First, the main basis of the game is the negative externality problem arising from the fact that an unsustainable fiscal position and a threat of default by one EMU member is likely to spillover on the rest of EMU members. As indicated earlier, since the birth of the euro the negative externality problem has been central to all policy debates related to EMU's institutional design. In fact, it has been one of the key arguments in favor of the Stability and Growth Pact: imposing fiscal rules on EMU members would - as it was hoped - counter the tendency for fiscal bias and free riding. ${ }^{3}$ Also in the context of the recent euro area crisis Baldwin, Gros and Laeven (2010) point out that “(...) in a monetary union without a fiscal union governments might be tempted to run up unsustainable debts and push the ECB to inflate them away or run up high levels of debts that would create negative spillovers for others." Substantial negative externality effects have been also confirmed empirically. For example, Faini (2006) has shown that expansionary fiscal policy in one EMU member state has an effect not only on the spreads of this particular member's interest rates, but also - and to an even greater extent - on the average level of interest rates in the whole euro area. In essence, the costs of fiscal profligacy are paid not only by the sinner, but also by other members ${ }^{4}$.

Such negative externality may take different forms. For example, decreased political support for European integration process, deteriorated financial market access, protracted growth slack or disrupted trade relations (henceforth we call them 'externality costs'). ${ }^{5}$ Because the above costs adversely affect all the members, such externality may serve as a bargaining leverage that a particular member can use for negotiating redistribution - a bail-out - of its costs of fiscal adjustment within EMU. While such concessions may in principle take pecuniary form (for example, some sort of fiscal transfers) or non-pecuniary form (for example, loosening some rules in face of deteriorating fiscal position), in the following discussion we focus on the former compensation.

\footnotetext{
${ }^{3}$ For the early discussions on the rationales for the Stability and Growth Pact and its provisions see for example, Artis and Winkler (1998), Beetsma and Uhlig (1999), Brunila et al. (2001) or Buti and Sapir (2006).

${ }^{4}$ It is worth noting that it did not seem to work this way during the current Greek crisis. In fact, German interest rates fell down in reaction to Greek woes, whereas those of Spain, Portugal or Ireland increased.

${ }^{5}$ Note that the negative externality arises here in the political economics context. On purely economic considerations it can be argued that letting Greece default could be efficient as it would strengthen incentives for structural reforms among all EMU countries. In other words the default would lead to some sort of "positive externality'. However, reforms that eventually benefit all are often resisted or delayed and a growing body of literature explains how such "inefficient" outcomes can be compatible with rational behavior (e.g, Rodrik (1996)).
} 
Second, there are two types representative players involved in the game. Within EMU there are a group of countries which suffer from the twin problems of public debt sustainability and external debt sustainability. These 'twin deficit' countries - think of Greece, Spain or Portugal - are labeled 'TD'. The second group of countries - think of Germany - is characterized by current account surpluses within the euro area and sustainable public debt position (henceforth labeled 'CA'). ${ }^{6}$ Later we assume that only one particular $\mathrm{TD}_{i}-$ think of Greece - faces an imminent default risk, although other TDs are susceptible. This assumption allows us to bring the structure of the model closer to the ongoing discussion and to take into account the potential contagion effect on other TDs and its implications for final bargaining outcome. $^{7}$

Third, there is incomplete political integration among the players: Countries have different incentives to be EMU member, face different constituency constraints and there is no automatic emergency financing mechanism for unwinding severe fiscal and macroeconomic imbalances in EMU. In fact, for this reason, a fierce bargaining within European fiscal affairs has recently evolved.

Both representative players TD and CA are interested in preserving smooth functioning of EMU. From the viewpoint of TD, membership in the euro area is advantageous as it provides access to financial markets and to real external resources (as euro loosens external constraints for TD). At the same time, membership in the euro area is beneficial for CA, as it supports its export-oriented policy stance (due, inter alia, to a slower growth of its relative unit labor costs) - a reversal of this policy stance and associated adjustment of production processes would incur CA with short run costs.

Against this background there exits a public good 'EMU stability', whose deterioration in the course of one member's default would make all players worse off. While the individual

\footnotetext{
${ }^{6}$ Sustainability of public finances is understood here in relative terms. While such a relative position is key for the financial markets in the short and medium-run which is the focus of this analysis, one has to remember that due to the ageing problem, all EU member countries face severe challenges for their public finances. According to the OECD, with no policy change only because of demographic changes, the average debt rises to $500 \%$ of GDP in 2060).

${ }^{7}$ The IMF was an important player during negotiations over the bail-out. For simplicity, we do not formally include the IMF into the game. However, integrating the IMF into the model would increase the bargaining power of $\mathrm{TD}_{i}$ (as has been the case with Greece) which would strengthen the case for bail-out. Integrating into the model another external actor would also not rule out the issue of negative externality stemming from the institutional set-up of EMU.
} 
motivation is different, the interest in preserving a smooth operation of EMU is shared by all players. Hence, both TD and CA have some willingness-to-pay for preserving EMU stability and their membership within EMU.

This mutual willingness-to-pay for 'EMU stability' is the foundation of bargaining for redistribution of players' cost shares within EMU. In this context, an individual TD player may resort to a brinkmanship strategy, as its potential default would create a negative 'externality cost', i.e. a Damocles sword hanging over the rest of EMU members. Within the scope and limits of such brinkmanship strategy, CA might be credibly threatened to actually reveal its willingness-to-pay for 'EMU stability'. Accordingly, TD may effectively elicit a bail-out by the rest of EMU members. Importantly, for all players there is the risk of an overall worst outcome for such maneuvering on the brink - this worst outcome constitutes the threat, which is not under full control by the players. As soon as it turns out that the threat is indeed credible brinkmanship ensues. Our analysis then inquires into a Nash bargaining solution (NBS) for that conflict which completes the entire threat game. We show to what extent a single TD may indeed pass some of the 'fiscal adjustment costs' on to the rest of EMU, i.e. successfully incur CA with some of the burden of financial assistance.

The analysis unfolds in three steps: First, we discuss the basic characteristics of such a threat game. Second, the brinkmanship is elaborated. Third, we determine a sub-game perfect equilibrium for successful brinkmanship, i.e. eliciting bail-outs within EMU.

\section{The model}

A single $\mathrm{TD}_{i}$ (denoted as player $j=1$, whereas $\left.i=1, \ldots, n\right)$ and a representative CA (player $j=2$ in place of the group of current account surplus countries within the euro area) are two risk-neutral players with quasi-linear preferences for the public good 'EMU stability'. The first player $\mathrm{TD}_{i}$ has complete but imperfect information regarding CA's willingness-topay for preserving a smooth functioning of EMU. As mentioned above, the reason for distinguishing between particular TDs is that there might be a contagion effect (i.e. a negative externality) in the course of a likely bail-out of a single twin deficit country. Furthermore, we assign bargaining power to both players: $\alpha_{i}$ is the bargaining power of a $\operatorname{TD}_{i}$ and $\beta_{-i}$ the particular corresponding bargaining power of $\mathrm{CA}$, with $\alpha_{i}+\beta_{-i}=1$. At the heart of our 
brinkmanship game is the haggling between the $\mathrm{TD}_{i}$ and $\mathrm{CA}$ over sharing the costs of fiscal adjustments within EMU, i.e. contributions to safe-guarding 'EMU stability'. These costs are denoted as $C_{i}^{F}$ (henceforth, 'fiscal adjustment costs') for the specific $\mathrm{TD}_{i}$. By the same token, benefits with respect to a single $\mathrm{TD}_{i}$ are denoted as $B_{i}$ - these benefits stand for preserving membership within EMU and providing access to financial markets and external resources. From the perspective of $\mathrm{CA}$, the same $B_{i}$ represents the benefits from euro area membership as prerequisite for its export-oriented stance. ${ }^{8}$

In this regard, another issue concerns the limited liability feature of CA, which is the extent to which CA countries within the euro area actually pay for TDs' failure in fiscal consolidation. A deterioration of the public good 'EMU stability' entails above all costs for $\mathrm{TD}_{i}$. However, CA will also suffer from a default as it has a stake in EMU. Though, CA has a particular subsidiary role: While $\mathrm{TD}_{i}$ will not accept costs higher than total $C_{i}^{F}$ in exchange for contributing to 'EMU stability', CA will administer financial assistance within the limits of their maximum willingness to pay if $C_{i}^{D}>C_{i}^{F}$. Accordingly, CA will have limited liability amounting to a share $\lambda_{i}$ of total $C_{i}^{F}$ with $0<\lambda_{i} \leq 1$. This is to say, CA countries will at most transfer funds to $\mathrm{TD}_{i}$ amounting to $C_{i}^{F}$, because beyond that point their willingness to pay for preserving 'EMU stability' would be exhausted, too. The following proposition can be derived from these considerations:

$$
\lambda_{i}= \begin{cases}0 & \text { if } C_{i}^{F} \geq C_{i}^{D} \\ 0<\lambda_{i}<1 & \text { if } C_{i}^{F}<C_{i}^{D}<2 C_{i}^{F} . \\ 1 & \text { else }\end{cases}
$$

Bearing the entire $C_{i}^{F}$ reflects each player's maximum willingness to pay for successful managing Greek-type crises within EMU. In this regard, $C_{i}^{F}$ reflects each player's cost tolerance in escalation processes of brinkmanship. The rationale of such brinkmanship is that $\mathrm{TD}_{i}$ threatens to realize the overall worst pay-off represented in the disagreement point $d$. In doing so, it can under identifiable conditions pass a share of the fiscal adjustment costs, $C_{i}^{F}$,

\footnotetext{
${ }^{8}$ We assume that the benefits are the same for both players as it renders the game simpler to solve. One may rightly argue that benefits can be different for, say, a big economy like Germany and, say, a small one like Greece. However, assuming that the benefits were not symmetric would not change the general tone of our results, so we have decided to keep the game as simple as possible.
} 
on the rest of the EMU members. If a credible brinkmanship evolves, then both players will not maximize their piece of the pie, but minimize their respective share of fiscal adjustment $C_{i}^{F}$ during negotiations. The present bargaining problem is thus characterized by the tuple ( $C_{i}, d$ ) where $C_{i} \subset R_{+}^{* 2}$ is a vector combination of feasible (dis)utility allocations. The disagreement point $d$ is the bargaining outcome if both parties' negotiations break down. In that case, markets will notice that both $\mathrm{TD}_{i}$ and $\mathrm{CA}$ cannot agree on an appropriate policy solution for $\mathrm{TD}_{i}$ that helps safe-guarding 'EMU stability', i.e. redistributing the 'fiscal adjustment costs' amounting to $C_{i}^{F}$. This will then, in turn, trigger a default. This way the realization of $d$ is equivalent to the occurrence of default costs $C_{i}^{D}$. The following costs arise in this game $G\left(C_{i}^{F}, d\right)$ : First, there are the above mentioned 'fiscal adjustment costs' $C_{i}^{F}$ for bail-outs around which the bargaining revolves. If the according negotiations on distributing $C_{i}^{F}$ were to break down, then a default will occur, and both players will be stuck with the disagreement point $d$ comprising the actual 'default costs' $C_{i}^{D}$ and $\lambda_{i}$ respectively.

Further reservations regarding the delineated basic characteristics of this brinkmanship game are as follows: On the one hand, the question arises whether TDs should form a cartel to strengthen their brinkmanship vis-à-vis other EMU members. On the other hand, whether other EMU countries within the euro area can announce in advance that they will club together in order to punish the first country which dares to practice brinkmanship. This is to say that they might pursue an enter-deterrence game. However, because of the coordination problem and competition between all EMU members both scenarios are unlikely. As to the first scenario, if it becomes evident that some particular TDs explicitly coordinate brinkmanship strategy then this may lead financial markets and other members of EMU to discriminate more between both group of countries, TDs and CAs. Also, since - as we have assumed before - only $\mathrm{TD}_{i}$ is facing an imminent default risk, other TDs will not be willing to join as it might signal the financial markets that they also face an imminent default risk. As to the second scenario, the coordination problem among CA countries arises because of uncertainty regarding their future potential need for assistance. ${ }^{9}$

\footnotetext{
${ }^{9}$ The scope for an enter-deterrence game is limited also by the fact that due to problems of effective monitoring, assessing fiscal policy and identifying deliberate infringement to fiscal rules in EMU is a complicated issue (e.g. Jaeger and Schuknecht (2004) discussing it in the context of pro-cyclical fiscal positions and boom-bust phases). As regards boom-bust cycles within EMU please also refer to Backé and Wójcik (2008).
} 
Successful brinkmanship is especially dependent on the two given probabilities $p$ and $q_{i}$ that are independent of each other and endogenous. The latter say depicts the fact that the cost structure determines the probability values. From the perspective of a $\mathrm{TD}_{i}, p$ denotes the probability of encountering an 'offish' CA or a 'lavish' one with a probability $(1-p)$. The more offish the CA, the lower is the probability of executing successful brinkmanship. At this stage, we take up on the point that $\mathrm{T}_{i}$ as an EU member has a say in the European decision-making process. Hence, CA may link financial assistance as a tool when seeking a $\mathrm{TD}_{i}$ 's consent to any agreement. In line with this rationale, we assume that values of $p$ are smaller than 1 . At the same time $p>0$ because CA has at least some willingness to pay for preserving 'EMU stability' (see above). Hence, we reject according corner solutions of $p$, so that $0<p<1$.

The probability $q_{i}$ basically describes the likelihood of externalities by triggering voter alienation towards enacted fiscal consolidation processes, i.e. incurring the electorate with the full amount of 'fiscal adjustment costs' $C_{i}^{F} \cdot{ }^{10}$ Uncertainty regarding the constituency's reaction to stipulated fiscal retrenchment processes may buttress $\mathrm{TD}_{i}$ 's bargaining position in negotiations vis-à-vis CA. If the electorate was completely 'Europhile', then there would be no room for the government for incurring other EMU members with any form of externality costs as imposed fiscal austerity would not havoc any political upheaval. In fact, the according probability $q_{i}$ would be zero in such circumstances. At the same time, we expect that voters as well as their delegated governments must also rank the benefits $B_{i}$ as valuable. Otherwise, any efforts towards fiscal consolidation within $\mathrm{TD}_{i}$ would be unacceptable, and a government would be unable to craft consensus towards its contribution to safe-guarding 'EMU stability' in the domestic arena. In line with the aforementioned reasoning, we exclude according corner solutions so that $0<q_{i}<1$. There accordingly exist some political resources on the national level, which a government in $\mathrm{TD}_{i}$ may play off against $\mathrm{CA}$ in intergovernmental European negotiations.

\footnotetext{
${ }^{10}$ Here, national strikes in Greece provide a vivid example how political imponderability on the national level may bring about a bargaining leverage in international negotiations.
} 
If the conditions for successful brinkmanship are met, then $\mathrm{CA}$ will dance obligingly to $\mathrm{TD}_{i}$ 's tune and share some 'fiscal adjustment costs' $C_{i}^{F}$ in terms of providing a bail-out. In the following paragraphs, we determine the Nash strategies, i.e. the mutually best responses which will eventually constitute a sub-game perfect Nash equilibrium of the brinkmanship game.

\section{The brinkmanship game}

We proceed with the analysis of the political-economic, game-theoretic model by simplifying things without loss of generality: Given that both players' maximum willingness to pay for 'EMU stability' in terms of still reaping the benefits $B_{i}$ from smooth operation of the euro area corresponds to the total $C_{i}^{F}$, we can normalize $C_{i}^{F}=B_{i}=1$. Hence, we can transform the threat game $G\left(C_{i}, d\right)$ to the form of $\Gamma\left(\varsigma_{i}, d\right)$ with $0<c_{i j} \leq 1, c_{i j} \in \varsigma_{i}, \varsigma_{i} \subset R_{+}^{* 2}$. The standard assumption holds that $\varsigma_{i}$ is a non-empty, convex and compact set comprising any convex combination of vector $c_{i j}=\left(c_{i 1}, c_{i 2}\right)$. In this game $\Gamma\left(\varsigma_{i}, d\right) \mathrm{TD}_{i}$ quasi maximizes the CA's share of 'fiscal adjustment costs' for safe-guarding 'EMU stability', i.e. incurring them with the costs of their negative externality. The bargaining may lead to a new outcome $c_{i}$ for $\operatorname{TD}_{i}$. In turn, $\mathrm{TD}_{i}$ burdens $\mathrm{CA}$ with the share $1-c_{i}$. Accordingly, the players' continuous utility functions $u_{(i) j}\left(c_{(i) j}\right)$ are:

$$
\begin{aligned}
& u_{i 1}\left(c_{i 1}\right)=c_{i 1}=c_{i}, \\
& u_{2}\left(c_{i 2}\right)=c_{i 2}=\left(1-c_{i}\right) .
\end{aligned}
$$

At the same time, the brinkmanship game $\Gamma\left(\varsigma_{i}, d\right)$ still comprises the disagreement point $d-$ i.e. the realization of default costs $C_{i}^{D}$ - and represents $\mathrm{TD}_{i}$ 's threat, where the pay-off is $\left(-1,-\lambda_{i}\right)$ in line with the aforementioned proposition (see above).

\section{Contagion and moral hazard effects}

Two different sub-games of $\Gamma\left(\varsigma_{i}, d\right)$ due to complete but imperfect information have to be taken into consideration. First, $\mathrm{TD}_{i}$ does not know whether it will encounter an offish $(p)$ or a lavish $(1-p)$ CA. In this context, specific default costs have to be considered. On the one 
hand, a single crisis has the potential to trigger further defaults of all $n \mathrm{TD}_{i}$. This would be the overall worst pay-off from the viewpoint of CA. Therefore, fearing such exorbitant costs the primary goal of $\mathrm{CA}$ would be to sustain the support in each $\mathrm{TD}_{i}$ for safe-guarding 'EMU stability'. From this point of view, it may be more beneficial to be lavish. Second, CA may display a rather reluctant attitude towards providing bail-outs because any obvious generosity would intensify moral hazard behavior which possibly does require transferring $n$-times of $c_{i}$. Due to CA's ambiguous attitude towards providing extra funding, the $\mathrm{TD}_{i}$ 's pay-offs have to be weighted with a probability $p$ for encountering an offish and $(1-p)$ for a lavish CA.

The $\mathrm{TD}_{i}$ 's feasible set of strategies is comprised of two choices: 'consolidate' or 'not-toconsolidate'. The latter strategy consists of practicing brinkmanship on the basis of the premise that national constituency would not accept consolidation measures. If $\mathrm{TD}_{i}$ chooses to 'consolidate', i.e. not practicing brinkmanship, it forgoes the opportunity to pass a share $c_{i}$ of 'fiscal adjustment costs' on to CA. This would be the best pay-off from the perspective of CA. When $\mathrm{TD}_{i}$ relies on a strategy of choosing 'not-to-consolidate', the outcome ultimately depends on the reaction of CA. The latter player can choose a strategy of 'bail-out' or 'nobail-out' by withholding any funding. The according pay-offs are as follows: If $\mathrm{TD}_{i}$ chooses a strategy of 'consolidate', then it receives zero, whereat CA receives the entire benefits of secured 'EMU stability', i.e. further smooth operation of euro area, amounting to 1 . If $\mathrm{TD}_{i}$ chooses to 'not-to-consolidate', CA can 'bail-out' or 'no-bail-out'. When CA reins $\mathrm{TD}_{i}$ 's prospective default in, then $\mathrm{TD}_{i}$ receives the aspired alleviation of 'fiscal adjustment costs' in amount of $c_{i}$. In this case CA receives a pay-off $\left(1-c_{i}\right)$. Taking into account the principle of equal treatment within Europe, however, CA may also have to deal with transferring payments to all $\mathrm{TD}_{i}$ amounting to $n$ times the size of $\left(1-c_{i}\right)$. If CA chooses to 'no-bail-out', $\mathrm{TD}_{i}$ may be stuck with default costs amounting to $\left(-q_{i}\right)$. The latter pay-off hinges upon $\mathrm{TD}_{i}$ 's likelihood of losing public support for fiscal retrenchment and consequently defaulting. Simultaneously, CA receives the pay-off $\left(-q_{i} \lambda_{i}+1-q_{i}\right)$ or $\left(-q_{i} \sum_{i=1}^{N} \lambda_{i}+1-q_{i}\right)$ in the case of possibly spreading defaults among all TDs. 
A brinkmanship strategy has to meet some prerequisite conditions. In particular, a successful brinkmanship has to be effective and acceptable. The effectiveness condition of such brinkmanship rests on the extent of $\mathrm{TD}_{i}$ 's default: As CA is increasingly affected by costs, a $\mathrm{TD}_{i}$ 's threat gains more credibility. In this respect, the probability of default is subject to a critical threshold: If the respective probability is too small, CA cannot be coerced into providing financial assistance. However, the credibility of the brinkmanship strategy is also dependent on whether the outcome is acceptable to $\mathrm{TD}_{i}$. If the probability of a default is too high and, hence, the acceptability condition cannot be accomplished, then $\mathrm{TD}_{i}$ will have to 'consolidate'. In turn, this player will entirely incur the envisioned 'fiscal adjustment costs' for sustaining 'EMU stability'.

The $\mathrm{TD}_{i}$ 's brinkmanship will be successful, which means eliciting the desired extra funds amounting to $c_{i}$, if it constitutes a credible threat. In this regard, $\mathrm{TD}_{i}$ 's brinkmanship may be effective, if the expected pay-off of CA from a choice to 'bail-out' is higher than from a decision to 'no-bail-out' when taking into account possible contagion, i.e. defaults spilling over to other TDs. Therefore,

$$
\left(-q_{i} \sum_{i=1}^{N} \lambda_{i}+1-q_{i}\right)<\left(1-c_{i}\right)
$$

Accordingly, the minimum probability $q_{i, \min }$ has to be:

$$
q_{i, \min }>\frac{c_{i}}{\sum_{i=1}^{N} \lambda_{i}+1} .
$$

The probability $q_{i, \min }$ is the lower bound of the brinkmanship for $\mathrm{TD}_{i}$. Below this level CA would choose a strategy of 'no-bail-out', even if it is lavish. However, with a probability of $p \mathrm{TD}_{i}$ may feel that the strategy 'not-to-consolidate' is too risky with regard to encountering an offish $\mathrm{CA}$. At the same time, $\mathrm{TD}_{i}$ will encounter a lavish $\mathrm{CA}$ with a probability of $(1-p)$, which will choose a strategy of 'bail-out' given that the effectiveness condition holds. Thus, for a given $0<q_{i}<1 \mathrm{TD}_{i}$ will pose a probabilistic threat, if its expected pay-off is higher than a zero pay-off from choosing to 'consolidate':

After resolving we obtain:

$$
\left(-q_{i} p\right)+c_{i}(1-p)>0 .
$$

$$
q_{i, \max }<c_{i} \frac{1-p}{p}
$$


Accordingly, the acceptability condition depends on values for $p$. Therefore, values for $p$ have to be below a critical threshold. Otherwise, $q_{i, \max }$ would have to be even smaller than $q_{i, \min }$ for some high values of $p$. That would render any brinkmanship fruitless as it indeed becomes effective but not acceptable. From the proposition $q_{i, \min }<q_{i, \max }$ it follows that the upper bound is:

$$
p_{\max }<\frac{\sum_{i=1}^{N} \lambda_{i}+1}{\sum_{i=1}^{N} \lambda_{i}+2}<1 .
$$

If the probability $p$ for an offish CA satisfies the acceptability condition, then the following proposition must be valid:

$$
p^{*} \in P^{*}, \quad P^{*}:=\left\{p^{*} \mid p^{*}<p_{\max }<1, p^{*} \in R_{+}^{*}\right\} .
$$

Regarding $q_{i, \min }$, the probability $q_{i}$ in a brinkmanship strategy has to remain below the critical threshold $q_{i, \max }$. Above that value $\mathrm{TD}_{i}$ will refrain from a strategy of 'not-toconsolidate' because it fears mutual detrimental effects. Therefore, for every given probability $0<p<1$ the probabilistic threat is credible when a country-specific $q_{i}^{*}$ is an element of the finite set $Q_{i}^{*}$. The according proposition is:

$$
q_{i}^{*} \in Q_{i}^{*}, \quad Q_{i}^{*}:=\left\{q_{i}^{*} \mid q_{i, \min }<q_{i}^{*}<q_{i, \max }, q_{i}^{*} \in R_{+}^{*}\right\} .
$$

When the endogenous effectiveness and acceptability conditions for the parameters $p$ and $q_{i}$ are satisfied, $\mathrm{TD}_{i}$ will resort to brinkmanship. CA's response to $\mathrm{TD}_{i}$ 's brinkmanship is to immediately transfer 'fiscal adjustment costs' amounting to the share $c_{i}$. This is equivalent to $\mathrm{TD}_{i}$ passing the respective portion of 'fiscal adjustment costs' on to current EMU members, i.e. the bail-out in the face of such negative externalities. At this stage, then $\mathrm{TD}_{i}$ will henceforth commit to fiscal consolidation since there are no further opportunities to pass costs on to current account surplus countries of the euro area. This is because beyond that point CA is no longer willing to pay for safe-guarding 'EMU stability'. The remainder of the gametheoretic analysis focuses on the Nash bargaining solution for distributing $\mathrm{TD}_{i}$ 's 'fiscal adjustment costs' during a Greek-type crisis for EMU. This is to say that we ascertain each player's portion of such fiscal costs.

\section{The bargaining game}


An NBS is characterized by complete information. It is finite in that only one offer and no counter-offers are possible when bargaining. The bargaining revolves around arguing over sharing the 'fiscal adjustment costs' of safe-guarding 'EMU stability'. Given that all characteristics of the game are common knowledge, the players look ahead and anticipate the reciprocal best responses. Due to this backward induction, negotiation time is irrelevant and the bargaining game comes to an immediate solution. In line with this rationale, present seesawing - in terms of announcing and stipulating fiscal retrenchment on the Greek level and deliberating upon bail-outs at European end - is representing the preparatory stage before both camps finally put their cards on the table.

The game $\Gamma\left(c_{i}, d\right)$ is completed by a Nash bargaining on the non-empty, convex and compact set comprising any convex combination of vector $\left(c_{1}, c_{2}\right)$ in $R_{+}^{* 2}$. According to the NBS it has to be dealt with Pareto-efficient solutions only. The particular share $c_{i}$ of 'fiscal adjustment costs', which $\mathrm{TD}_{i}$ can load on to $\mathrm{CA}$, is the bargaining outcome. The NBS is derived from the Nash product (NP) weighted with the respective bargaining power:

$$
\max _{c_{i j}} N P\left(\Gamma\left(\varsigma_{i}, d\right)\right)=\left(u_{i 1}\left(c_{i 1}\right)-u_{i 1}\left(d_{1}\right)\right)^{\alpha_{i}}\left(u_{2}\left(c_{i 2}\right)-\left(u_{2}\left(d_{2}\right)\right)^{\beta_{-i}}\right.
$$

with $c_{i j} \geq d_{j}, c_{i j} \in \varsigma_{i}, \alpha_{i} \geq 0, \beta_{-i} \geq 0$, and $\alpha_{i}+\beta_{-i}=1$.

Given the players' utility functions the maximization problem in light of $d=\left(-1,-\lambda_{i}\right)$ is:

$$
\max _{c_{i 1}, c_{i 2}} \Gamma\left(\varsigma_{i}, d\right)=\left(c_{i}+1\right)^{\alpha_{i}}\left(\left(1-c_{i}\right)+\lambda_{i}\right)^{\beta_{-i}} .
$$

The according first-order condition is:

$$
\left.\frac{d N P}{d c_{i}}=\alpha_{i}\left(c_{i}+1\right)^{\alpha_{i}}\left(\left(1-c_{i}\right)+\lambda_{i}\right)\right)^{\beta_{-i}}-\left(c_{i}+1\right)^{\alpha_{i}} \beta_{-i}\left(\left(1-c_{i}\right)+\lambda_{i}\right)^{\beta_{-i}}=0 .
$$

After rearranging we receive the equilibrium solution:

$$
c_{i}^{*}= \begin{cases}\text { not defined } & \text { if } \frac{\left(1+\lambda_{i}\right) \alpha_{i}-\beta_{-i}}{\alpha_{i}+\beta_{-i}} \leq 0 \\ 0<c_{i} \leq 1 & \text { if } 0<\frac{\left(1+\lambda_{i}\right) \alpha_{i}-\beta_{-i}}{\alpha_{i}+\beta_{-i}} \leq 1 . \\ 1 & \text { else }\end{cases}
$$

Here, it becomes obvious that CA's actual willingness to pay for bailing out $\mathrm{TD}_{i}$ depends on the distribution of bargaining power. The less bargaining power $\beta_{-i} \mathrm{CA}$ exhibits, the higher are the values for $c_{i}^{*}$. Consequently, $\mathrm{TD}_{i}$ can elicit more funds amounting to $c_{i}^{*}$ from $\mathrm{CA}$ as their bargaining power $\alpha_{i}$ increases, hence, having other EMU members over the barrel. We 
recall that $c_{i}^{*}$ is the share of 'fiscal adjustment costs' $C_{i}^{F}$ that is acceptable to CA. With respect to the complete brinkmanship game $\Gamma\left(\varsigma_{i}, d\right)$ the NBS is, hence,

$$
\text { NBS: } \Gamma^{*}\left(\varsigma_{i}, d\right)=\left(c_{i}^{*},\left(1-c_{i}\right)^{*}\right) \text {. }
$$

Considering the specific characteristics of the NBS, the combination of both players' Nash strategies ['not-to-consolidate', 'bail-out'] can also be represented in terms of their respective reaction functions $R_{i j}$. Due to complete information $\mathrm{TD}_{i}$ can anticipate CA's optimal choice. Hence, its own best response is:

$$
R_{i 1}\left(c_{i 2}^{*}\right)= \begin{cases}\text { not defined } & \text { if } \frac{\left(1+\lambda_{i}\right) \alpha_{i}-\beta_{-i}}{\alpha_{i}+\beta_{-i}} \leq 0 \\ 0<c_{i} \leq 1 & \text { if } 0<\frac{\left(1+\lambda_{i}\right) \alpha_{i}-\beta_{-i}}{\alpha_{i}+\beta_{-i}} \leq 1 \\ 1 & \text { else }\end{cases}
$$

From the perspective of CA the corresponding reaction function is:

$$
R_{i 2}\left(c_{i 1}^{*}\right)= \begin{cases}\text { not defined } & \text { if } \frac{2 \beta_{-i}-\lambda_{i} \alpha_{i}}{\alpha_{i}+\beta_{-i}} \leq 0 \\ 0<\left(1-c_{i}\right) \leq 1 & \text { if } 0<\frac{2 \beta_{-i}-\lambda_{i} \alpha_{i}}{\alpha_{i}+\beta_{-i}} \leq 1 . \\ 1 & \text { else }\end{cases}
$$

The players' reaction functions $R_{i j}$ constitute the unique sub-game perfect Nash equilibrium incorporating a specific NBS of the entire game $\Gamma\left(\varsigma_{i}, d\right)$ and $G\left(C_{i}^{F}, d\right)$ respectively for every fixed $\bar{p} \mid \bar{p}^{*} \in P^{*}$ and $\bar{q} \mid \bar{q}^{*} \in Q^{*}$. This is to say that for effective and acceptable brinkmanship, CA's response to $\mathrm{TD}_{i}$ 's credible brinkmanship strategy is to burden itself with 'fiscal adjustment costs' $C_{i}^{F}$ amounting to the share of $c_{i}$. Thus, $\mathrm{TD}_{i}$ passes the respective 'fiscal adjustment costs' on to other EMU members. When obtaining a share $c_{i}$ of 'fiscal adjustment costs', $\mathrm{TD}_{i}$ will abstain from further attempts to promote a hazardous fiscal policy stance and will behave well. This is because, at that point, CA's willingness to pay for contributing to the public good 'EMU stability' is exhausted. So, there is no more moral hazard related to fiscal policy.

It is important to note that this outcome is primarily related, although not restricted to, to the parties directly involved in the negotiation process. ${ }^{11}$ It goes without saying that the exogenously invoked limited liability can be altered. However, increasing CAs' willingness-

\footnotetext{
${ }^{11}$ Additional analysis would be needed to see how this result may impact other player's behavior in the dynamic setting.
} 
to-pay would not change the general tone of the analysis on moral-hazard behavior. At least, this applies as long as it is assumed that EMU represents a joint public good. Henceforth, there must be some positive limited liability. However, in this respect, there might be another caveat in order: as the modeling framework reckons one TD's brinkmanship vis-à-vis CA, the Greek-type crisis has been one particular round in the 'boxing match', though such a crisis scenario may occur again. Insofar, one may expect that newly incipient but random sovereign debt crisis within EMU to mark the starting point for another round of the outlined threat game. Hence, the institutional setup of EMU is the ground for brinkmanship, whereas 'crisis' acts as a catalyst within the overall process.

\section{Conclusions and policy implications}

The Greek crisis involved intense negotiations among the euro area members and depended to a large extent on political factors. In this paper, we have presented a framework that formally takes account of the interactions between the economic and political factors in such type of a crisis in the context of the EMU. We have based our analysis on a political-economic, gametheoretic model that helps to understand why and how the parties involved in the Greek crisis arrived at the bail-out and on what conditions the final solution depended. In doing so, we have formally taken account of the negative externality problem that is central to all policy debates related to the EMU's institutional design and played an important role in the Greek crisis. However, contrary to the existing literature, we have not only focused on the economic aspect of such negative externality, but also looked at how it emanates and interact with the political factors, in particular the dynamics of the political negotiation process within the EMU. Based on our analysis, we have demonstrated that the bail-out was inevitable (i.e. a threat of default by one member must (under identifiable conditions) result in sharing the costs of fiscal adjustment by the rest of the members) but that it does not have to be associated with a future moral hazard problem.

As regards the policy implications, it is important to stress that the results are conditional on the present political-economic set-up of the EMU. In other words, the EMU problems do not only ensue from the Greek fiscal problems alone, but from the interactions of these problems with the actual political-economic configuration of the EMU. The sheer fact that countries share the same currency does not necessarily have to lead to negative spillovers between 
them. If this was the case, the fiscal problems in Ecuador, a dollarized country, would give rise to a threat to the dollar - evidently this is not the case (see more Balcerowicz (2010)). In the EMU, however, refinancing difficulties of a small country like Greece which accounts for only $2 \%$ of the euro area's GDP can trigger a systemic crisis for the whole EMU. This is different from the case of the US monetary union where fiscal woes of even such big states as California do not wreak such havoc.

The weakness of the current EMU set-up is that it neither provides sufficient incentives for curtailing excessive lending and indebtedness (see more De Haan et al. (2004)), nor secures the degree of political integration necessary to attain a sufficient degree of policy coordination. Strengthening fiscal discipline is of key importance, but it has consistently collided with the enforceability problem of applying supra-national fiscal rules to sovereign states. While stepping-up the degree of political integration could alleviate this tension, policy makers in Europe are well aware of how lengthy this process would be and how naïve it is to believe that political integration could be significantly accelerated.

Squeezed between the undesirable now and the long-to-attain future, the EMU needs to develop some intermediate solutions that would help to bridge this gap. Our analysis suggests at least a few possible avenues (see also Fahrholz and Wójcik (2010)).

First, should a bail-out be unavoidable, given the current state of the political-economic configuration of the EMU - as our analysis seems to suggest - then it is better to make it rulebased and explicit. This may at least limit the haggling and uncertainty in the course of such events resulting in a lower risk premium associated with such uncertainty (see Bini Smaghi (2010) who makes a similar case in context of financial markets). This would also render support for the European Monetary Fund suggested earlier by Gros and Mayer (2010).

Second - and this is our main conclusion - the analysis suggests that, in order to improve the EMU's functioning, more weight should be given to solutions which address the negative externality problem. This could be achieved by changing the political incentives in the negotiation processes of the EMU. In a sense, this would address the political aspect of the political-economic set-up of the EMU and hence would complement the necessary (but so far largely failed) efforts to improve the EU and domestic fiscal frameworks per se. One such 
solution could be to establish 'exit rules'. Specifying conditions for leaving the EMU, including the costs and legal requirements of such an operation, would bring at least three benefits: i) on the constituency level, it would make exit costs explicit to electorates, thus diminishing incentives to follow such strategies; ii) on the government level, it would weaken the bargaining position of troubled countries vis-à-vis the rest of EMU, thus decreasing the effectiveness of brinkmanship strategies; iii) on the markets level, it would reduce uncertainty and stabilize market reaction in case of a future potential default or exit, thus decreasing the scope for negative externality.

Overall, making exit costs and procedures explicit would increase the perceived costs of an exit relative to the short-term political costs of economic adjustment. This would serve as a deterrent to brinkmanship, stimulate fiscal discipline and decrease the scope for the negative externality. While additional research is needed to shed more light on the effects of such exit rules, it seems that the existence of the rules would strengthen the EMU's sustainability in the long-run, both in economic and political terms. Paradoxically, it may make future exits less not more - probable, as shown by the history of certain national states struggling to preserve their internal integration (cf. The Economist 2005). Their experience suggests that when secession is not permitted, a pressure for it rises. When secession is openly allowed, many would-be secessionists cease to press so hard for it - or for a bail-out as is the case with the Greek-type crisis. 


\section{References}

Acemoglu, Daron. 2003. "Why not a Political Coase Theorem? Social Conflict, Commitment, and Politics." Journal of Comparative Economics, 31:4, 620-652.

Alesina, Alberto and Allan Drazen. 1991. "Why are Stabilizations Delayed?” American Economic Review, 81:5, 1170-1188

Artis, Michael J. and Bernhard Winkler. 1998. "The Stability Pact: Safeguarding the Credibility of the European Central Bank.” National Institute Economic Review, 163, 87-98.

Backé, Peter and Cezary Wójcik. 2008. "Credit booms, monetary integration and the new neoclassical synthesis.” Journal of Banking \& Finance, 32:3, 458-470.

Balcerowicz, Leszek. 2010. "Sovereign Bankruptcy in the EU in the Comparative Perspective." Paper presented at the XII Travemünde Symposium zur ökonomischen Analyse des Rechts, Travemünde, 24-26 March 2010.

Baldwin, Richard, Daniel Gros, and Luc Laeven. 2010. Completing the Eurozone Rescue: What More Needs to Be Done. VoxEU.org e-Book, 17 June 2010. URL: http://www.voxeu.org/index.php?q=node/5194.

Beetsma, Roel and Harald Uhlig. 1999. "An Analysis of the Stability and Growth Pact." Economic Journal, 109:458, 546-571.

Binmore, Ken, Ariel Rubinstein, and Asher Wolinsky. 1986. "The Nash Bargaining Solution in Economic Modelling." Rand Journal of Economics, 17:2, 176-188.

Buti, Marco and Andre Sapir. 2006. "Fiscal Policy in Europe: The Past and Future of EMU Rules from the Perspective of Musgrave and Buchanan.” CPER Discussion Paper No. 5830.

Brunila, Anne, Marco Buti, and Daniele Franco. 2001. The Stability and Growth Pact: The Architecture of Fiscal Policy in EMU. Basingstoke: Palgrave Macmillan.

Bini Smaghi, Lorenzo. 2010. "It is better to have explicit rules for bail-outs." Financial Times, 16 March 2010.

Bordo, Michael D. and Lars Jonung. 1999. "The future of EMU: What does the history of monetary union tells us?” NBER Working Paper 7365.

de Haan, Jakob, Helge Berger, and David-Jan Jansen. 2004. "Why has the stability and growth pact failed?" International Finance, 7:2, 235-260.

De Grauwe, Paul. 2010. "How to embed the Eurozone in a political union." VoxEU.org, 17 June 2010. URL: http://www.voxeu.org/index.php?q=node/5166.

Dixit, Avinash. 2006. "Thomas Schelling's Contributions to Game Theory." Scandinavian Journal of Economics, 108:2, 213-229.

Dixit, Avinash and Barry Nalebuff. 2008. The Art of Strategy. New York, NY: Norton.

Dye, Alan and Richard Sicotte. 2006. "How Brinkmanship Saved Chadbourne: Credibility and the International Sugar Agreement of 1931." Explorations in Economic History, 43:2, 223-256.

The Economist. 2005. "Clarity needed. How to respond to perennial demands from separatists in Spain." 21 April 2005. URL: http://www.economist.com/node/3888034.

Eichengreen, Barry. 2010. "Europe's Trojan Horse." Project Syndicate, 15 February 2010. URL: http://www.project-syndicate.org/commentary/eichengreen14/English.

Fahrholz, Christian. 2007. "Bargaining for Costs of Convergence in Exchange Rate Mechanism II: A Rubinstein Threat Game.” Journal of Theoretical Politics, 19:2, 193-214.

Fahrholz, Christian and Cezary Wójcik. 2010. "Global financial crisis and the future of EMU." Journal of Regulation and Risk North Asia, 2:2-3, 175-183.

Faini, Riccardo. 2006. "Fiscal Policy and Interest Rates in Europe.” Economic Policy, 21:47, 443-489.

Fisher, Jonas, Lars Jonung and Martin Larch. 2006. "101 Proposals to reform the Stability and Growth Pact. Why so many? A Survey." European Commission Directorate-General for Economic and Financial Affairs European Economy Economic Papers No. 267.

Frankel, Jeffrey. 2010. "Let Greece go to the IMF." Jeff Frankel Blog, 12 February 2010. URL: http://belfercenter.ksg.harvard.edu/analysis/frankel/?p=441.

Gros, Daniel and Thomas Mayer. 2010. "How to deal with sovereign default in Europe: Create the European Monetary Fund now!” CEPS Policy Brief No. 202, 17 May 2010.

Gros, Daniel, Thomas Mayer, and Angel Ubide. 2005. EMU at Risk - 7th Annual Report of the CEPS Macroeconomic Policy Group. CEPS e-Book, June 2005. URL: http://www.ceps.eu/node/1076.

Iida, Keisuke. 1993. "When and How Do Domestic Constraints Matter - 2-Level Games with Uncertainty." Journal of Conflict Resolution, 37:3, 403-426.

Issing, Otmar. 2010. "A Greek bail-out would be a disaster for Europe.” Financial Times, 16 February 2010.

Jaeger, Albert and Ludger Schuknecht. 2007. "Boom-Bust Phases in Asset Prices and Fiscal Policy Behavior." Emerging Markets Finance and Trade, 43:6, 45-66.

Mao, Wen. 1993. "Commitments to Threat Strategies in Nash Bargaining." International Journal of Game Theory, 22:2, 141-151. 
Mayer, Thomas. 2010. "What more do European governments need to do to save the Eurozone in the medium run?" VoxEU.org, 17 June 2010. URL: http://www.voxeu.org/index.php?q=node/5173.

Milner, Helen V. and B. Peter Rosendorff. 1997. "Democratic Politics and International Trade Negotiations." Journal of Conflict Resolution, 41:1, 117-146.

Nash, John F. 1950. “The Bargaining Problem.” Econometrica, 18, 155-162.

Nash, John F. 1953. "Two-Person Cooperative Games.” Econometrica, 21, 128-140.

Padoa-Schioppa, Tommaso. 2010. "EU Shouldn't Abandon Greece.” Financial Times, 20 February 2010.

Rodrik, Dani. 1996. "The Positive Economics of Policy Reforms," Papers and Proceedings of the Hundred and Fifth Annual Meeting of the American Economic Association (May, 1993), American Economic Review, 83:2, 356-361.

Tarar, Ahmer. 2001. "International Bargaining with Two-Sided Domestic Constraints." Journal of Conflict Resolution, 45:3, 320-340.

Schelling, Thomas C. 1960. Strategy of Conflict. Cambridge, MA: Harvard University Press.

Schwarz, Michael and Konstantin Sonin. 2008. "A Theory of Brinkmanship, Conflicts, and Commitments." Journal of Law, Economics, \& Organization, 24:1, 163-183.

Wyplosz, Charles. 2010. "The Greek bailout won't work." BusinessSpectator, 5 May 2010. URL: http://www.businessspectator.com.au/bs.nsf/article/greek-crisis-eurozone-greece-ecb-debt-pd2010050455ceq?opendocument\&src=blb.

Yared, Pierre. 2010. “A Dynamic Theory of War and Peace.” Journal of Economic History, 145:5, 1921-1950.

Zagare, Frank C. and D. Marc Kilgour 2000. Perfect Deterrence. Cambridge, UK: Cambridge University Press. 


\section{CESifo Working Paper Series}

for full list see www.cesifo-group.org/wp

(address: Poschingerstr. 5, 81679 Munich, Germany, office@cesifo.de)

3115 John Beirne, Guglielmo Maria Caporale and Nicola Spagnolo, Liquidity Risk, Credit Risk and the Overnight Interest Rate Spread: A Stochastic Volatility Modelling Approach, July 2010

3116 M. Hashem Pesaran, Predictability of Asset Returns and the Efficient Market Hypothesis, July 2010

3117 Dorothee Crayen, Christa Hainz and Christiane Ströh de Martínez, Remittances, Banking Status and the Usage of Insurance Schemes, July 2010

3118 Eric O’N. Fisher, Heckscher-Ohlin Theory when Countries have Different Technologies, July 2010

3119 Huw Dixon and Hervé Le Bihan, Generalized Taylor and Generalized Calvo Price and Wage-Setting: Micro Evidence with Macro Implications, July 2010

3120 Laszlo Goerke and Markus Pannenberg, 'Take it or Go to Court' - The Impact of Sec. 1a of the German Protection against Dismissal Act on Severance Payments -, July 2010

3121 Robert S. Chirinko and Daniel J. Wilson, Can Lower Tax Rates be Bought? Business Rent-Seeking and Tax Competition among U.S. States, July 2010

3122 Douglas Gollin and Christian Zimmermann, Global Climate Change and the Resurgence of Tropical Disease: An Economic Approach, July 2010

3123 Francesco Daveri and Maria Laura Parisi, Experience, Innovation and Productivity Empirical Evidence from Italy's Slowdown, July 2010

3124 Carlo V. Fiorio and Massimo Florio, A Fair Price for Energy? Ownership versus Market Opening in the EU15, July 2010

3125 Frederick van der Ploeg, Natural Resources: Curse or Blessing?, July 2010

3126 Kaisa Kotakorpi and Panu Poutvaara, Pay for Politicians and Candidate Selection: An Empirical Analysis, July 2010

3127 Jun-ichi Itaya, Makoto Okamura and Chikara Yamaguchi, Partial Tax Coordination in a Repeated Game Setting, July 2010

3128 Volker Meier and Helmut Rainer, On the Optimality of Joint Taxation for NonCooperative Couples, July 2010

3129 Ryan Oprea, Keith Henwood and Daniel Friedman, Separating the Hawks from the Doves: Evidence from Continuous Time Laboratory Games, July 2010 
3130 Mari Rege and Ingeborg F. Solli, The Impact of Paternity Leave on Long-term Father Involvement, July 2010

3131 Olaf Posch, Risk Premia in General Equilibrium, July 2010

3132 John Komlos and Marek Brabec, The Trend of BMI Values by Centiles of US Adults, Birth Cohorts 1882-1986, July 2010

3133 Emin Karagözoğlu and Arno Riedl, Information, Uncertainty, and Subjective Entitlements in Bargaining, July 2010

3134 John Boyd, Gianni De Nicolò and Elena Loukoianova, Banking Crises and Crisis Dating: Theory and Evidence, July 2010

3135 Michael R. Baye, Dan Kovenock and Casper G. de Vries, The Herodotus Paradox, July 2010

3136 Martin Kolmar and Hendrik Rommeswinkel, Group Contests with Complementarities in Efforts, July 2010

3137 Carolina Manzano and Xavier Vives, Public and Private Learning from Prices, Strategic Substitutability and Complementarity, and Equilibrium Multiplicity, July 2010

3138 Axel Löffler, Gunther Schnabl and Franziska Schobert, Inflation Targeting by Debtor Central Banks in Emerging Market Economies, July 2010

3139 Yu-Fu Chen and Michael Funke, Global Warming and Extreme Events: Rethinking the Timing and Intensity of Environmental Policy, July 2010

3140 Lawrence M. Kahn, Labor Market Policy: A Comparative View on the Costs and Benefits of Labor Market Flexibility, July 2010

3141 Ben J. Heijdra, Jochen O. Mierau and Laurie S.M. Reijnders, The Tragedy of Annuitization, July 2010

3142 Erkki Koskela, Outsourcing Cost and Tax Progression under Nash Wage Bargaining with Flexible Outsourcing, July 2010

3143 Daniel Osberghaus and Christiane Reif, Total Costs and Budgetary Effects of Adaptation to Climate Change: An Assessment for the European Union, August 2010

3144 Philip E. Graves, Benefit-Cost Analysis of Environmental Projects: A Plethora of Systematic Biases, August 2010

3145 Sabrina Di Addario and Daniela Vuri, Entrepreneurship and Market Size. The Case of Young College Graduates in Italy, August 2010

3146 Shoshana Amyra Grossbard and Alfredo Marvăo Pereira, Will Women Save more than Men? A Theoretical Model of Savings and Marriage, August 2010 
3147 Jarko Fidrmuc, Time-Varying Exchange Rate Basket in China from 2005 to 2009, August 2010

3148 Ilja Neustadt and Peter Zweifel, Is the Welfare State Sustainable? Experimental Evidence on Citizens' Preferences for Redistribution, August 2010

3149 Marcus Dittrich and Andreas Knabe, Wage and Employment Effects of Non-Binding Minimum Wages, August 2010

3150 Shutao Cao, Enchuan Shao and Pedro Silos, Fixed-Term and Permanent Employment Contracts: Theory and Evidence, August 2010

3151 Ludger Woessmann, Cross-Country Evidence on Teacher Performance Pay, August 2010

3152 Lorenzo C. G. Pozzi, Casper G. de Vries and Jorn Zenhorst, World Equity Premium Based Risk Aversion Estimates, August 2010

3153 Volker Grossmann, Thomas M. Steger and Timo Trimborn, Dynamically Optimal R\&D Subsidization, August 2010

3154 Alexander Haupt, Tim Krieger and Thomas Lange, A Note on Brain Gain and Brain Drain: Permanent Migration and Education Policy, August 2010

3155 António Afonso and Christophe Rault, Long-run Determinants of Sovereign Yields, August 2010

3156 Franziska Tausch, Jan Potters and Arno Riedl, Preferences for Redistribution and Pensions. What can we Learn from Experiments?, August 2010

3157 Martin Kolmar and Andreas Wagener, Inefficient Group Organization as Optimal Adaption to Dominant Environments, August 2010

3158 Kai Carstensen, Klaus Wohlrabe and Christina Ziegler, Predictive Ability of Business Cycle Indicators under Test: A Case Study for the Euro Area Industrial Production, August 2010

3159 Horst Rottmann and Timo Wollmershäuser, A Micro Data Approach to the Identification of Credit Crunches, August 2010

3160 Philip E. Graves, Appropriate Fiscal Policy over the Business Cycle: Proper Stimulus Policies Can Work, August 2010

3161 Michael Binder and Marcel Bluhm, On the Conditional Effects of IMF Program Participation on Output Growth, August 2010

3162 Michael Binder, Qianying Chen, and Xuan Zhang, On the Effects of Monetary Policy Shocks on Exchange Rates, August 2010

3163 Felix J. Bierbrauer, On the Optimality of Optimal Income Taxation, August 2010 
3164 Nikolaus Wolf, Europe's Great Depression - Coordination Failure after the First World War, September 2010

3165 Dan Kovenock and Brian Roberson, Conflicts with Multiple Battlefields, September 2010

3166 Jean-Pierre Ponssard and Catherine Thomas, Capacity Investment under Demand Uncertainty. An Empirical Study of the US Cement Industry, 1994-2006, September 2010

3167 Jørgen Juel Andersen, Jon H. Fiva and Gisle James Natvik, Voting when the Stakes are High, September 2010

3168 Michael Hoel, Is there a Green Paradox?, September 2010

3169 Scott Alan Carson, Nineteenth Century US African-American and White Female Statures: Insight from US Prison Records, September 2010

3170 Gil S. Epstein, Yosef Mealem and Shmuel Nitzan, Political Culture and Discrimination in Contests, September 2010

3171 Sara Fisher Ellison, Jeffrey Greenbaum and Wallace P. Mullin, Diversity, Social Goods Provision, and Performance in the Firm, September 2010

3172 Silvia Dominguez-Martinez, Randolph Sloof and Ferdinand von Siemens, Monitoring your Friends, not your Foes: Strategic Ignorance and the Delegation of Real Authority, September 2010

3173 Marcus Dittrich and Beate Schirwitz, Union Membership and Employment Dynamics: A Note, September 2010

3174 Francesco Daveri, Paolo Manasse and Danila Serra, The Twin Effects of Globalization - Evidence from a Sample of Indian Manufacturing Firms, September 2010

3175 Florian Blöchl, Fabian J. Theis, Fernando Vega-Redondo and Eric O’N. Fisher, Which Sectors of a Modern Economy are most Central?, September 2010

3176 Dag Morten Dalen, Marilena Locatelli and Steinar Strøm, Longitudinal Analysis of Generic Substitution, September 2010

3177 Armin Falk, Stephan Meier and Christian Zehnder, Did we Overestimate the Role of Social Preferences? The Case of Self-Selected Student Samples, September 2010

3178 Christian Fahrholz and Cezary Wójcik, The Bail-Out! Positive Political Economics of Greek-type Crises in the EMU, September 2010 